\title{
Validation of persuasive messages for the promotion of physical activity among people with coronary heart disease
}

\author{
Roberto Della Rosa Mendez ${ }^{1}$ \\ Roberta Cunha Matheus Rodrigues ${ }^{2}$ \\ Thaís Moreira Spana ${ }^{1}$ \\ Marília Estevam Cornélio \\ Maria Cecília Bueno Jayme Gallani² \\ Amalia Raquel Pérez-Nebra ${ }^{3}$
}

Objective: to validate the content of persuasive messages for promoting walking among patients with coronary heart disease (CHD). The messages were constructed to strengthen or change patients' attitudes to walking. Method: the selection of persuasive arguments was based on behavioral beliefs (determinants of attitude) related to walking. The messages were constructed based in the Elaboration Likelihood Model and were submitted to content validation. Results: the data was analyzed with the content validity index and by the importance which the patients attributed to the messages' persuasive arguments. Positive behavioral beliefs (i.e. positive and negative reinforcement) and self-efficacy were the appeals which the patients considered important. The messages with validation evidence will be tested in an intervention study for the promotion of the practice of physical activity among patients with CHD.

Descriptors: Nursing; Coronary Disease; Persuasive Communication; Validation Studies; Motor Activity.

\footnotetext{
${ }^{1}$ Doctoral students, Departamento de Enfermagem, Faculdade de Ciências Médicas, Universidade Estadual de Campinas, Brazil.

2 PhD, Associate Professor, Departamento de Enfermagem, Faculdade de Ciências Médicas, Universidade Estadual de Campinas, Brazil.

${ }^{3} \mathrm{PhD}$, Professor, Centro Universitário de Brasília, Brazil.
} 


\section{Validação de mensagens persuasivas para promoção de atividade física entre coronariopatas}

Objetivo: validar o conteúdo de mensagens persuasivas para promover a caminhada entre pacientes com doença arterial coronária (DAC). As mensagens foram construídas com vistas ao fortalecimento/mudança da atitude do paciente em relação à caminhada. Método: a seleção dos argumentos persuasivos foi baseada nas crenças comportamentais (determinantes da atitude), relacionadas à caminhada. As mensagens foram construídas com base no Modelo de Probabilidade de Elaboração e submetidas à validade de conteúdo. Resultados: os dados foram analisados por meio do índice de validade de conteúdo e pela importância atribuída pelos pacientes aos argumentos persuasivos das mensagens. As crenças comportamentais positivas (i.e. reforço positivo e negativo) e a autoeficácia foram os apelos considerados importantes pelos pacientes. As mensagens com evidências de validação serão testadas em estudo de intervenção para promoção da prática de atividade física entre pacientes com DAC.

Descritores: Enfermagem; Doença das Coronárias; Comunicação Persuasiva; Estudos de Validação; Atividade Motora.

\section{Validación de mensajes persuasivos para promoción de actividad física entre pacientes con coronariopatía}

Objetivo: validar el contenido de mensajes persuasivos para promover la caminata entre pacientes con enfermedad arterial coronaria (DAC). Los mensajes fueron construidos objetivando al fortalecimiento/cambio de la actitud del paciente con relación a la caminata. Método: la selección de los argumentos persuasivos fue basada en las creencias comportamentales (determinantes de la actitud) relacionadas a la caminata. Los mensajes fueron construidos con base en el Modelo de Probabilidad de Elaboración y sometidos a la validez de contenido. Resultados: los datos fueron analizados por medio del índice de validez de contenido y por la importancia atribuida por los pacientes a los argumentos persuasivos de los mensajes. Las creencias comportamentales positivas (ejemplo: refuerzo positivo y negativo) y la autoeficacia fueron los reclamos considerados importantes por los pacientes. Los mensajes con evidencias de validación serán testadas en estudio de intervención para promoción de la práctica de actividad física entre pacientes con DAC.

Descriptores: Enfermería; Enfermedad Coronaria; Comunicación Persuasiva; Estudios de Validación; Actividad Motora.

\section{Introduction}

The participation of patients with coronary heart disease (CHD) in cardiovascular rehabilitation programs has been shown to be an effective strategy in controlling cardiovascular risk factors in treatment and in the prevention of further ischemic events ${ }^{(1)}$, in the reducing morbidity/mortality rates ${ }^{(2)}$ and in the improvement of quality of life in this group ${ }^{(3)}$.

Despite the benefits of physical activity in controlling the progression of $\mathrm{CHD}$, low compliance has been observed among patients with $\mathrm{CHD}^{(4)}$, which has stimulated the development/implementation of interventions ${ }^{(5)}$, particularly concerning models for behavioral change(6) with the objective of promoting compliance with the practice of physical activity.
One of the theoretical models widely used for understanding individuals' motivations in modifying specified behaviors is the Theory of Planned Behavior $\mathrm{TPB}^{(7)}$. According to the TPB the behavior is predicted by Intention (motivation), which in its turn is determined by three determinants - Attitude (negative/positive evaluations about the behavior), the Social Norm (the individual's perception of the social pressure to put the behavior into practice) and Perceived Behavior Control, which refers to the individual's perception of his or her ability to perform the behavior ${ }^{(7)}$.

Among patients with $\mathrm{CHD}$, the application of the TPB has shown that the PBC and Attitude are important predictors of individuals' Intention to 
adhere to the practice of physical activity after an ischemic event ${ }^{(6,8)}$.

In Brazil, a previous study ${ }^{(8)}$ undertaken with these patients evidenced that at the time of discharge from hospital, the intention of walking was determined by the PBC: one month after discharge, the variables of attitude, PBC and Past behavior explained the variance of intention.

Thus, the development and implementation of interventions aimed at strengthening/changing Attitude may contribute to increasing the adoption of physical activity among patients with CHD in the period following discharge from hospital(9).

Although the shaping of attitude is a rapid and automatic process profoundly influenced by the context, past history and the individual's current situation, changing it involves more complex steps ${ }^{(10)}$. Changing attitude depends on persuasion(11), which in its turn depends on how the receptor interprets and responds to its elements. In addition to the receptor, the emitter, the message and the context are important elements $^{(11)}$.

Among persuasion's theoretical references, one that stands out is the Elaboration Likelihood Model $(E L M)^{(12)}$, a framework that organizes the processes responsible for changing attitude. According to the ELM, persuasion may occur through routes: the Central route, which involves greater reflection on or elaboration of the information contained in the messages, and the Peripheral route, which refers to processes which require little reflection ${ }^{(13)}$. In general, attitudes which result from central route processes involve greater mental effort, and tend to be more consistent, longer-lasting, and more predictive of behavior, when compared to those resulting from the peripheral route.

A recent review study(14) emphasized the importance of searching for evidence for constructing messages which can transform the recommendations of physical activity guidelines ${ }^{(1)}$ into behavior. These messages should be emphatic and persuasive and aim at significantly changing the determinants of behavior linked to physical activity ${ }^{(14)}$

Thus, with the purpose of supporting future studies on intervention for promoting physical activity among CHD patients, the present study aimed at validating the content of persuasive messages promoting walking among patients with coronary disease. It is expected that this study's results will contribute to the construction of evidence about persuasive arguments to motivate physical activity among patients with CHD.

\section{Method}

\section{Selection of the persuasive arguments}

The selection of persuasive arguments for constructing messages with the objective of strengthening and/or changing Attitude was based on beliefs relating to the practices of physical activity. According to the TPB, attitudes are the result of a specific group of beliefs relating to behavior, named 'behavioral beliefs', which are associated with individuals' expectations of obtaining positive or negative results through carrying out the behavior in question. Behavioral beliefs are the result of life experience, and may be acquired directly, from observation, or indirectly, through information from other sources observation, or may be self-generated(7).

Thus, in the present study, the selection of persuasive arguments was based on a previous study ${ }^{(15)}$ which identified - in line with the assumptions of the TPB - the behavioral beliefs of the patients with $\mathrm{CHD}$ concerning the behavior of walking. The results of that study(15), evaluated by means of content analysis, evidenced that the behavioral beliefs relating to walking are those which reflect the possible benefits of the physical activity for health in general and, in particular, for cardiovascular health, which show the subject's disposition for walking, and which are related to emotion, as well as to those that evidence the possible disadvantages of the physical activity. Based on the behavioral beliefs ${ }^{(15)}$ and on the principles of persuasion, in accordance with the ELM(12), ten messages were constructed for motivating patients with CHD to adhere to the regular practice of walking.

It is to be emphasized that the messages were constructed with the intention of persuading by the two routes proposed by the model: peripheral and central. Access to the peripheral route of persuasion was hypothesized by the non-necessity for scrutiny of the message, while persuasion through the central route was accomplished through messages centered on the individual, that is, those which put forward arguments on why the individual should practice walking.

The benefits of physical activity, emotion, negative reinforcement and limitedness were used as the principle persuasive elements, limitedness being considered the last of the six appeals of persuasion(16). The limitedness, in the messages constructed, refers to the perception that the heart is a limited item and to the perception of loss. Negative reinforcement, in its turn, refers to the appeal for adoption of a behavior through the withdrawal of an aversive stimulus (which causes displeasure) or which avoids some negative consequence of the adoption of the behavior ${ }^{(17)}$. 


\begin{tabular}{|l|l|}
\hline 1. Keep on walking. Avoid a heart attack & 6. Keep your heart active. Walk! \\
\hline 2. Go for a walk. Your heart says thanks! & 7. Walk. The best person for taking care of your health is you \\
\hline 3. Walk. Live longer and better! & 8. Why walk? To have a better life! \\
\hline 4. Walk for a long life & 9. Be determined: include walking in your life! \\
\hline 5. Help your heart. Go for a walk with it & 10. Overcome your obstacles and walk \\
\hline
\end{tabular}

Figure 1 - Preliminary version of the persuasive messages concerning physical activity, submitted for evaluation by the Committee of Judges

\section{Validation of the persuasive messages}

Validation by the Committee of Judges

The messages were submitted for evaluation by five judges with recognized knowledge in the area, who met at least one of the following criteria: knowledge in teaching and researching in the area of persuasive communication; experience in the use of the TPB's theoretical framework; recognized methodological knowledge in designing intervention studies and/or experience in teaching, assistance, and research in caring for the patient with CHD.

The judges' evaluation was based on the following properties - clarity (if the persuasive messages were described in an understandable way); relevancy (if they express a genuine relationship with the proposal of the study in question); and persuasion (if they may be considered persuasive). Each property was evaluated by a Likert scale with points which varied from 1 to 5 (for example, $1=$ definitely not clear, $2=$ not clear, $3=$ not possible to evaluate, $4=$ clear and $5=$ definitely clear). If an item was classified as 'definitely not clear', or 'not clear', 'definitely not relevant' or 'not relevant', 'definitely not persuasive' or 'not persuasive', suggestions for modification were requested.

The judges also recommended that the messages should be illustrated to facilitate the understanding and to increase the impact of the appeal contained in each. The illustrations were produced by a designer (Figure 2) who was advised about the study's objectives and the target population's sociodemographic characteristics, and were submitted for evaluation by members of the research group.

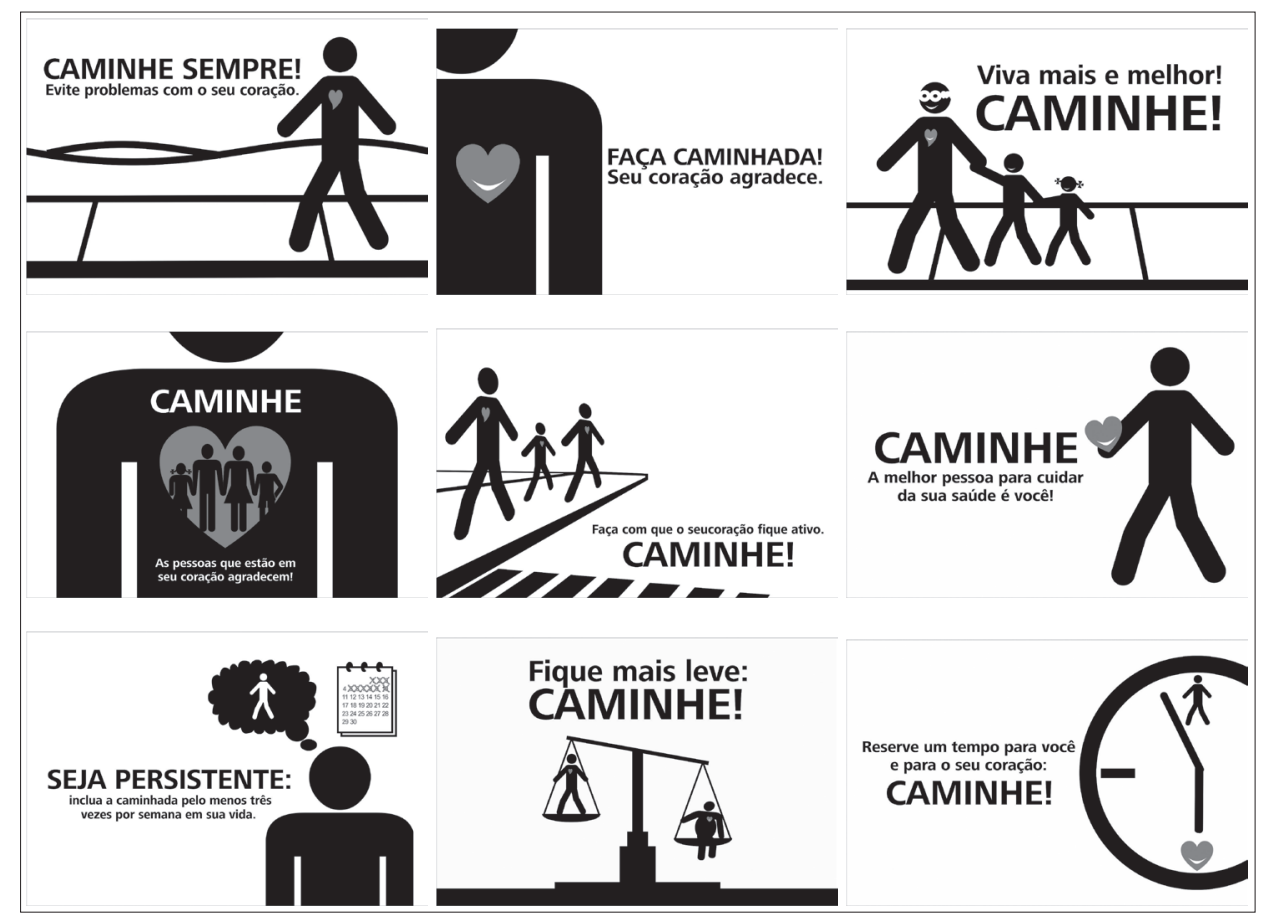

Figure 2 - Persuasive messages constructed with the aim of promoting the behavior of walking among patients with $\mathrm{CHD}$ 
Validation by the patients

The final version of the persuasive messages obtained after the experts' validation was applied to ten patients with CHD under outpatient cardiology treatment in a city in the state of Mato Grosso do Sul. The application of the messages was undertaken in a group, in a private setting, in the above-mentioned field of research. The individuals selected had been diagnosed with CHD, had medical release and had no medical limits for performing physical activity.

The following instruction was provided for applying the messages to the patients: We are going to show you ten messages constructed to encourage people with heart problems to walk. We would like your opinion in relation to the importance of each one in encouraging you to walk. Please number them in order of importance - from the most important to the least important. Consider that ' 1 ' corresponds to the most important message, and ' 9 ' the least important. Remember that there is no right and wrong here - what matters is your opinion.

\section{Data analysis}

The calculation of the Content Validity Index (CVI) ${ }^{(18)}$ was used for analyzing the content validation (Judges' Committee) stage, which measures the proportion or percentage of judges who are in agreement about the evaluation of the messages. The CVI was calculated by summing the items which received scores of 4 or 5 , divided by the total number of responses. Responses with a score of 3 were excluded from this calculation. The messages which obtained a CVI $\leq 0.80$ were excluded and/or reformulated. After this first evaluation, a new set of nine messages was re-submitted for evaluation by the same judges who had participated in this stage.

For evaluating the application of the messages to the patients stage, the researchers analyzed the patients' responses in relation to the importance they attributed to each of the messages. The average was calculated for the responses obtained for each message. Considering that a decreasing order of importance was used (from 1 to 9), the lowest average corresponded to the message considered the most important, and the highest to the least important. The messages were ranked according to the averages obtained.

\section{Ethical Aspects}

The Project was approved by the local Research Ethics Committee (Decision n 1227/2009).

\section{Results}

\section{Results of the evaluation by the Committee of Judges}

The proportion of agreement among the specialists regarding the messages' clarity, relevance and persuasiveness is presented in Table 1.

The results of the judges' first analysis showed that the messages 3,6 and 7 obtained a CVI $\geq 0.8$ for all the criteria evaluated, being considered relevant, clear and persuasive. The remaining messages obtained a CVI $<0.8$ in one or more properties, and were modified or excluded, as detailed below.

Message \#2 - Go for a walk. Your heart says thanks! obtained a CVI=0.6 and was considered, by one of the evaluators, to be of low persuasiveness, due to its strictly physical appeal. The suggestion was made to add emotional appeal. However, as affective appeal was used in Message \#5, it was decided not to change Message 2.

Messages 1, 5 and 9 also obtained CVI below that desired and were modified. Message 1 - "Keep on walking. Avoid a heart attack" was considered to be of low relevance and persuasiveness. The term "heart attack" was considered of little relevance to Brazilian culture, apart from being difficult to understand and of low persuasiveness, due to one of the evaluators considering that the patients with $\mathrm{CHD}$ already had the information contained in the message. It was suggested to add objective details of how much (as a percentage) walking would avoid a further cardiac event. However, the inclusion of objective data was decided against, as, in addition to the development, this would require skill in decoding, which was considered improbable in the population studied. For this reason, the message was modified to "Keep walking. Avoid problems with your heart".

Message \#5 - "Help your heart. Go for a walk with $i t^{\prime \prime}$, was considered only moderately clear and persuasive, due to the absence of greater affective appeal, as in the example of message 2 . The suggestion was heeded and the message was modified to - "Walk. The people you hold in your heart say thank you!" 
Table 1 - Scores obtained in the evaluation by the Committee of Judges for the properties - clarity, relevance and persuasiveness for each of the persuasive messages with their respective Content Validity Indexes (CVI) - Campinas, São Paulo, Brazil, 2010

\begin{tabular}{|c|c|c|c|c|c|c|c|c|c|c|c|c|c|c|c|c|c|c|}
\hline \multirow[b]{2}{*}{ Messages } & \multicolumn{3}{|c|}{ Judge 1} & \multicolumn{3}{|c|}{ Judge 2} & \multicolumn{3}{|c|}{ Judge 3} & \multicolumn{3}{|c|}{ Judge 4} & \multicolumn{3}{|c|}{ Judge 5} & \multicolumn{3}{|c|}{ CVI } \\
\hline & $\underset{\frac{\pi}{U}}{\frac{\pi}{U}}$ & 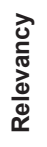 & $\begin{array}{l}\frac{5}{0} \\
\frac{0}{0} \\
\frac{\pi}{2} \\
0 \\
\frac{0}{0} \\
0\end{array}$ & $\frac{\frac{7}{\frac{\pi}{2}}}{\frac{\pi}{U}}$ & 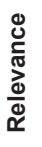 & $\begin{array}{l}\frac{5}{0} \\
\frac{0}{D} \\
\frac{0}{0} \\
\frac{0}{0} \\
\frac{0}{0} \\
0\end{array}$ &  & 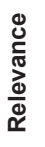 & $\begin{array}{l}\frac{5}{0} \\
\frac{0}{0} \\
\frac{0}{J} \\
0 \\
\frac{0}{0} \\
0\end{array}$ & 胥 & 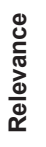 & $\begin{array}{l}\text {. } \\
\frac{0}{3} \\
\frac{0}{J} \\
0 \\
\frac{0}{0} \\
0\end{array}$ & $\frac{\frac{7}{2}}{\frac{\pi}{U}}$ & 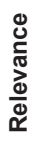 & $\begin{array}{l}\frac{5}{0} \\
\frac{0}{D} \\
\frac{\pi}{2} \\
\frac{0}{0} \\
0 \\
0\end{array}$ & $\begin{array}{l}\stackrel{2}{\frac{\pi}{2}} \\
\frac{\pi}{U}\end{array}$ & 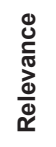 & $\begin{array}{l}\text { 은 } \\
\frac{0}{0} \\
\frac{\pi}{2} \\
\frac{0}{0} \\
0\end{array}$ \\
\hline 1. Keep on walking. Avoid a heart attack & $5^{*}$ & $2^{\dagger}$ & 2 & 4 & 4 & 3 & 5 & 2 & 3 & 5 & 4 & 2 & 5 & 5 & 5 & 1.0 & 0.6 & 0.2 \\
\hline 2. Go for a walk. Your heart says thanks! & 5 & 5 & 5 & 4 & 5 & 3 & 1 & 4 & 5 & 5 & 5 & 2 & 5 & 5 & 4 & 0.8 & 1.0 & 0.6 \\
\hline 3. Walk. Live longer and better! & 5 & 5 & 5 & 5 & 5 & 5 & 4 & 4 & 4 & 5 & 5 & 5 & 5 & 4 & 4 & 1.0 & 1.0 & 1.0 \\
\hline 4. Walk for a long life & $4 \S$ & 2 & 2 & 3 & 4 & 4 & 1 & 3 & 3 & 2 & 2 & 2 & 5 & 5 & 5 & 0.4 & 0.4 & 0.4 \\
\hline 5. Help your heart. Go for a walk with it & 4 & 4 & 4 & 2 & 4 & 3 & 3 & 3 & 5 & 4 & 4 & 2 & 4 & 5 & 5 & 0.6 & 0.8 & 0.6 \\
\hline 6. Keep your heart active. Walk! & 4 & 4 & 4 & 5 & 5 & 5 & 4 & 5 & 5 & 5 & 5 & 5 & 4 & 5 & 4 & 1.0 & 1.0 & 1.0 \\
\hline 7. Walk. The best person for taking care of your health is you & 5 & 5 & 5 & 5 & 5 & 4 & 4 & 3 & 4 & 5 & 5 & 5 & 5 & 4 & 4 & 1.0 & 0.8 & 1.0 \\
\hline 8. Why walk? To have a better life! & 2 & 4 & 3 & 4 & 5 & 4 & 4 & 3 & 3 & 2 & 4 & 2 & 5 & 5 & 4 & 0.6 & 1.0 & 0.4 \\
\hline 9. Be determined: include walking in your life! & 2 & 4 & $3^{\|}$ & 3 & 2 & 3 & 5 & 4 & 5 & 2 & 4 & 2 & 4 & 4 & 3 & 0.4 & 0.8 & 0.2 \\
\hline 10. Overcome your obstacles and walk & 2 & 4 & 2 & 2 & 4 & 1 & 2 & 2 & 2 & 2 & 4 & 2 & 4 & 4 & 3 & 0.2 & 0.8 & 0.0 \\
\hline
\end{tabular}

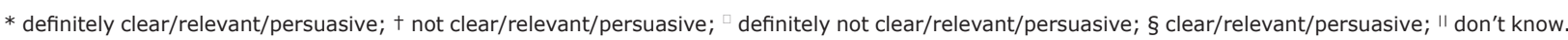

In its turn, Message 9 - "Be determined: include walking in your life!" was considered unclear and of low

persuasive value. The lack of clarity was related to the term "determined", which was considered difficult to understand and of low persuasiveness, and to the absence of concrete information relating to the amount of physical activity necessary for cardiovascular protection. The message was modified to meet the recommendations - "Be persistent: include a walk three times a week in your life".

Messages 4 -"Walk for a long life", 8 - "Why walk? To have a better life!" and 10 - "Overcome your obstacles and walk" were excluded. These messages received low scores in all the properties evaluated from at least one of the judges. Messages 4 and 8 received low scores in the evaluation of their persuasiveness due to the fact that they appealed to fear. The tenth message was considered generic, as it does not define the obstacles to accomplishing the behavior.

New messages were constructed to substitute the excluded messages, in line with the judges' suggestions. The construction of a message appealing to vanity was suggested, specifically, referring to the weight loss associated with undertaking physical activity. Thus, the message - "Lighten up: walk!" was included. To meet the suggestion of using an appeal involving time, the message "Reserve some time for you and your heart: walk!" was included.

In this way, at the end of the first stage, a set of nine messages was obtained, which was itself submitted for evaluation by the same judges. At this stage of the evaluation, however, only three judges returned the evaluation instrument filled out. In this evaluation, the majority of the messages obtained CVI $>0.80$, except for the message "Be persistent: include a walk at least three times a week in your life", which was considered moderately persuasive, as it did not include objective data about the consequences of adopting the behavior, such as the improvement of survival and quality of life. However, the position of not including quantitative information was maintained, under the hypothesis that it would complicate the development in terms of interpreting the information.

\section{Results of the evaluation by the patients}

The 10 patients reported that the nine messages were clear and stated that they did not experience difficulty in understanding them. In order to evaluate the persuasiveness, the patients were asked to list, in descending order, the messages that were most important in encouraging the carrying out of physical activity. The messages were ranked according to the averages obtained in positions which varied from $1^{\text {st }}$ to $8^{\text {th }}$ place (Figure 3), where the lowest average corresponded to the message considered the most important, and the highest, to the least important.

* Position (from 1 to 10 ) indicated by the patients in relation to the importance of each of the messages submitted to the pre-test, considering " 1 " as the most important and " 10 " as the least important message. The 


\begin{tabular}{|c|c|c|c|c|c|c|c|c|c|c|c|c|}
\hline \multirow{2}{*}{ Message } & \multicolumn{10}{|c|}{$\begin{array}{l}\text { Classification of the messages from } 1 \text { to } 10 \text {, according to } \\
\text { their importance for the Subjects }(\mathbf{S})^{*}\end{array}$} & \multirow{2}{*}{ Average } & \multirow{2}{*}{$\begin{array}{c}\text { Final } \\
\text { position in } \\
\text { the ranking }\end{array}$} \\
\hline & s1 & s2 & S3 & S4 & S5 & S6 & S7 & S8 & S9 & S10 & & \\
\hline $\begin{array}{l}\text { Be persistent: include a walk at least three times a week } \\
\text { in your life }\end{array}$ & 1 & 6 & 4 & 1 & 3 & 3 & 3 & 3 & 6 & 4 & 3.4 & $1^{\text {st }}$ \\
\hline Walk. The best person for taking care of your health is you & 3 & 5 & 3 & 7 & 5 & 2 & 1 & 2 & 5 & 2 & 3.5 & $2^{\text {nd }}$ \\
\hline Keep walking. Avoid problems with your heart & 2 & 1 & 9 & 3 & 6 & 8 & 4 & 1 & 1 & 7 & 4.2 & $3^{\text {rd }}$ \\
\hline Keep your heart active. Walk! & 8 & 3 & 7 & 2 & 7 & 1 & 2 & 7 & 3 & 3 & 4.3 & $4^{\text {th }}$ \\
\hline Go for a walk. Your heart says thanks! & 9 & 2 & 1 & 9 & 2 & 9 & 6 & 6 & 2 & 8 & 5.4 & $5^{\text {th }}$ \\
\hline Walk. The people you hold in your heart say thank you! & 7 & 4 & 2 & 8 & 1 & 6 & 8 & 8 & 4 & 9 & 5.7 & $6^{\text {th }}$ \\
\hline Walk. Live longer and better! & 5 & 9 & 6 & 6 & 4 & 5 & 7 & 5 & 9 & 1 & 5.7 & $6^{\text {th }}$ \\
\hline Reserve some time for you and your heart: walk! & 4 & 7 & 8 & 4 & 8 & 4 & 5 & 9 & 7 & 5 & 6.1 & $7^{\text {th }}$ \\
\hline Lighten up: walk! & 6 & 8 & 5 & 5 & 9 & 7 & 9 & 4 & 8 & 6 & 6.7 & $8^{\text {th }}$ \\
\hline
\end{tabular}

higher the average, the worse the position in the ranking.

Figure 3 - The messages' ranking for promoting physical activity, in descending order of importance in the pre-test among CHD patients under outpatient follow-up $(n=10)$

It was determined that the message - "Be persistent: include a walk at least three times a week in your life" was identified as the most important by the patients, followed by the messages "Walk. The best person for taking care of your health is you!" and "Keep walking. Avoid problems with your heart". On the other hand, the messages "Reserve some time for you and your heart: walk!" and "Lighten up: walk!" were considered as the lowest impact in motivating the performance of physical activity.

\section{Discussion}

The present study aimed at validating the content of a set of persuasive messages based on the ELM model(12), with a view to their application in a subsequent study for strengthening and/or changing attitudes in relation to the adoption by patients with CHD of the behavior of walking. The messages were constructed to change the attitude, that is one of the behavioral determinants of walking among persons with CHD, evidenced in a previous study conducted in Brazilian individuals with $\mathrm{CHD}^{(8)}$.

It was found, in the judges' first evaluation, that the constructed messages that were unclear and of low persuasiveness had low affective appeal involved in the construction of some of them. In fact, emotional appeal (with positive emotions) influences the recovery of positive experiences in the memory, being able to influence judgements, the preparation of strategies and the disposition to take on risks. Another important point of positive emotion is that it influences cognitive organization and the consequences of this for the resolution of problems ${ }^{(19)}$. In the present study, affective appeal was accomplished by appealing to others (affection for the family), as suggested by the judges ("Walk! The people you hold in your heart say thank you").

Some messages were considered to be of low persuasiveness due to their appealing to fear and/ or the consequences of non-adoption of the behavior. These were excluded. Although there are reports that appeals to fear are successful, as they create emotional responses which focus attention on how to deal with the problem(20), the use of this type of strategy is controversial. Studies have shown that with preventive behaviors - such as that of motivating the practice of physical activity - it is more effective to emphasize the benefits associated with a source with high credibility than to use the appeal to fear $r^{(9,21)}$.

A review study ${ }^{(5)}$ that evaluated the effectiveness of three approaches (message tailoring, message framing and messages for changing self-efficacy) in the construction of messages for promoting physical activity showed that the use of framing messages, constructed with emphasis on the benefits ("gain-framed") is more effective in promoting the behavior than those which appeal to the consequences ("loss-framed") of failure to adopt the target behavior. According to the review, the effects found in the Intention and in the behavior of physical activity are sufficiently consistent (Level 2 evidence) to recommend - with caution - the use of messages which emphasize the benefits, rather than messages which appeal to the consequences of nonadherence to the behavior. The recommendation for cautious use is due to the limited quality of the evidence, resulting from methodological limitations of the studies analyzed. 
Thus, the final set of messages constructed in the present study emphasizes positive content, with an emphasis on the benefits of physical activity - Positive reinforcement ("Go for a walk. Your heart says thanks!", "Walk. Live longer and better!", "Keep your heart active. Walk!", "Lighten up: walk!") and a single message with negative reinforcement - "Keep walking. Avoid problems with your heart". This message was considered by the patients to be the third most important for encouraging adherence to the practice of physical activity, after the messages - "Be persistent: include a walk at least three times a week in your life!" and "Walk. The best person for taking care of your health is you!"

In this way, the positive behavioral beliefs (i.e. positive and negative reinforcement) and self-efficacy, both proposed by the TPB model, were the appeals that, in the patients' opinions, were the most important for encouraging adherence to the practice of physical activity. It is worth noting that social norms, for this population, were less relevant, occupying sixth place of importance in the set of messages constructed.

\section{Conclusion}

It is concluded that after the process of content validation, the messages showed clarity, relevance and persuasive composition. A subsequent randomized intervention study with application of the validated messages could evidence the effect of this strategy in strengthening/changing attitude and, consequently, in increasing the CHD patients' intention (motivation) in adhering to an active lifestyle.

\section{References}

1. Smith SC, Benjamin EJ, Bonow RO, Braun LT, Creager MA, Franklin BA, et al. AHA/ACCF Secondary Prevention and Risk Reduction Therapy for Patients With Coronary and Other Atherosclerotic Vascular Disease: 2011 Update. A Guideline from the American Heart Association and American College of Cardiology Foundation. Circulation. 2011;124:2458-73.

2. Hammill BG, Curtis LH, Schulman KA, Whellan DJ. Relationship between cardiac rehabilitation and long-term risks of death and myocardial infarction among elderly medicare beneficiaries. Circulation. 2010;121:63-70.

3. Lisspers J, Sundin O, Ohman A, Hofman-Bang C, Ryden L, Nygren A. Long-term effects of lifestyle behavior change in coronary artery disease: effects on recurrent coronary events after percutaneous coronary intervention. Health Psychol. 2005;24(1):41-8.

4. Dorn J. Correlates of compliance in a randomized exercise trial in myocardial infarction patients. Med Sci Sports Exerc. 2001; 33:1081-9.

5. Latimer AE, Brawler LR, Bassett R. A systematic review of three approaches for constructing physical activity messages: What messages work and what improvements are needed? Int J Behav Nutr Phys Act. $2010 ; 7: 36$.

6. Blanchard C. Understanding exercise behaviour during home-based cardiac rehabilitation: a theory of planned behaviour perspective. Can J Physiol Pharmacol. 2008;86:8-15.

7. Vallance JK, Murray TC, Johnson ST, Elavsky S. Understanding physical activity intentions and behavior in postmenopausal women: an application of the theory of planned behavior. Int J Behav Med. 2011;18(2):139-49.

8. Mendez RDR. Fatores individuais determinantes da realização de atividade física pelos pacientes com síndrome coronária aguda após a alta hospitalar. [dissertação de mestrado]. Campinas (SP): Universidade Estadual de Campinas; 2008. 164 p.

9. Jones LW, Sinclair RC, Rhodes RE, Courneya KS. Promoting exercise behaviour: an integration of persuasion theories and the Theory of Planned Behavior. $\mathrm{Br}$ J Health Psychol. 2004;9(4):505-21.

10. Winkielman $P$, Cacioppo JT. Mind at ease puts a smile on the face: psychophysiological evidence that processing facilitation elicits positive affect. J Per Soc Psychol. 2004;81:989-1000.

11. Brinõl P, Ibáñez LC, Grande AB. Qué es Persuasión. 2. ed. Madrid: Ed. Bibliotheca Nueva; 2008. 270 p.

12. Petty RE, Cacioppo JT. The effects of involvement on response to argument quantity and quality: central and peripheral routes to persuasion. J Pers Soc Psychol. 1984;46:69-81.

13. Petty RE, Barden J, Wheeler SC. The elaboration likelihood model of persuasion: Developing health promotions to produce sustained behavior change. In: Di Clemente RJ, Crosby RA, Kegler M. Emerging theories in health promotion practice and research. San Francisco: Jossey-Bass; 2009.

14. Brawley LR, Latimer AE. Physical activity guides for Canadians: messaging strategies, realistic expectations for change, and evaluation. J Public Health. 2007; 98 (Suppl 2): s170-s184.

15. Gallani MCBJ. O exercício físico e o paciente infartado: determinantes comportamentais [tese de doutorado]. São Paulo (SP): Escola de Enfermagem da Universidade São Paulo; 2000. 
16. Cialdini RB. Influence: science and practice. Needham Heights, MA: Allyn e Bacon; 2001.

17. Baum MW. Compreender o behaviorismo. Porto Alegre: Artmed; 2006.

18. Alexandre NMC, Coluci MZO. Validade de conteúdo nos processos de construção e adaptação de instrumentos de medida. Cienc Saude Coletiva. 2011;16(7):3061-8.

19. Isen AM, Daubman KA. The influence of affect on categorization. J Pers Soc Psychol. 1984;47(6):1206-17. 20. Mowen JC, Minor MS. Comportamento do Consumidor. São Paulo. Perason Prentice Hall; 2003. 403 p.

21. Jones LW, Sinclair RC, Courneya KS. The effects of source credibility and message framing on exercise intentions, behaviors, and attitudes: an integration of the Elaboration Likelihood Model and prospect theory. J Appl Soc Psychol. 2003;33(1):179-96. 